\title{
Effect of dietary formic acid as replacement of streptomycin on growth and nutrient digestibility in broiler
}

\author{
EK Ndelekwute* ${ }^{1}$, KD Afolabi $^{1}$, HO Uzegbu ${ }^{2}$, EB Essien ${ }^{1}$ \\ ${ }^{1}$ Department of Animal Science, University of Uyo, Uyo, Nigeria; ${ }^{2}$ National Agricultural Extension Research, \\ Liaison Station, Ahmadu Bello; University, Zaria, Nigeria
}

\begin{abstract}
An eight week feeding trial was carried out to compare the effect of antibiotic growth promoter (streptomycin) (AGP) and formic acid (FA) on growth and nutrient digestibility in broiler. A number of 150 day old (Hubbard strain) birds were allocated in 05 dietary groups viz. control, control with $0.02 \%$ AGP, control with $0.25 \% \mathrm{FA}$, control with $0.50 \% \mathrm{FA}$, control with $0.75 \% \mathrm{FA}$. Each group was replicated thrice having 10 birds and the birds were fed diet and water ad libitum for 8 weeks. Apparent digestibility of nutrients was determined at the end of the experiment. A significantly $(p<0.05)$ reduced feed intake, improved feed: gain ratio and protein utilization were obtained for starter broilers fed $0.02 \%$ AGP, $0.5 \%$ FA and $0.75 \%$ FA. During finisher phase, AGP and $0.5 \%$ FA performed better in live weight, feed conversion ratio and protein utilization. Streptomycin and all the levels of FA resulted to better protein and ether extract digestibility. It may be suggested to use $0.50 \%$ FA in the diet of broilers in place of antibiotics.
\end{abstract}

Key words: broiler, formic acid, growth, nutrient digestibility, streptomycin

Bangladesh Animal Husbandry Association. All rights reserved. $\quad$ Bang. J. Anim. Sci. 2015. 44 (1): 69-74

\section{Introduction}

Certain strategies have been adopted by nutritionists to improve the performance of broiler chickens. Such includes addition of feed additives to broiler feeds such as antibiotics which act as growth promoters (Maynard et al. 1981). Antibiotics as feed additives are substances that are added to animal feeds to improve growth and other productivity parameters, treat clinically sick animals and preventing or reducing the effect of pathogens (Aalback et al. 2000). Antibiotics have been used in animal feed for about 50 years ever since the discovery, not only as an anti-microbial agent but also as a growth promoting agent (Aalback et al. 2000). Recent concern on the use of antibiotics has been the issue of antibiotic residue always associated with meat produced with antibiotics (Ndelekwute et al. 2012). Accumulation of antibiotics in meat has been reported to cause antibiotic resistance both in farm animals and humans who consume the meat (Ndelekwute et al. 2013). This has lead to total or partial ban in some countries such as the United States of America and countries of the European Union
(Dibner 2004). The removal of antibiotics in broiler diet could lead to fall in performance and profitability (Ndelekwute et al. 2012). To reduce the effect of this removal, the use of certain substances including organic acids, probiotics and prebiotics have been tested (Waldroup et al. 2005; Windisch et al. 2007; Wolfenden et al. 2007).

Organic acids are carboxylic acids which are weak in nature and do not completely dissociate in water (Dibner 2004). They were reported to induce endogenous secretions improved and exert antibacterial effect both in feed and in the gut (Paul et al. 2007), cumulating to better performance of animals (Dibner 2004). Formic acid is one of the organic acids with the structural formula $\mathrm{HCOOH}$ and naturally found in ants (Ndelekwute et al. 2010). It is one of the products of biochemical and fermentation processes in the body of animals (Maynard et al. 1981; Rodwell 2006). Its positive effect on nutrient digestibility and antibacterial action in the digestive tract has been reported (Ndelekwute et al. 2012). 


\section{Effect of formic acid and Streptomycin on Broilers}

The objective of this research was to compare the effect of an AGP (streptomycin) and FA (formic acid) on performance and nutrient utilization of broiler.

\section{Materials and Methods}

The design was completely randomized design (CRD). There were five dietary groups viz. 1: the control diet containing neither streptomycin nor FA, 2: containing $0.02 \%$ streptomycin, 3: containing $0.25 \% \mathrm{FA}, 4$ : containing $0.5 \% \mathrm{FA}$ and 5: containing $0.75 \%$ FA. Each treatment had 30 birds of Hubbard strain with 10 birds per replicate giving a total of 150 birds.

The feeding trial was conducted in an open sided poultry house. The birds were brooded for three weeks using kerosene stove as heat source. Adequate vaccination against Gumboro and Newcastle diseases was carried out. Prophylactic treatments were given to control coccidiosis, Chronic respiratory disease and bacteria diseases. Administration of vitamins and minerals through the drinking water at the first week and at intervals was done. The birds were feed and water given ad libitum. The feed contained conventional feedstuffs and other ingredients (Table 1 and 2). The diets were formulated using trial and error method (Olomu 1995).

Data on live weight and feed intake were collected and used to calculate the feed: gain ratio, protein intake and protein efficiency ratio. Apparent nutrient digestibility was carried out using total collection method (Ndelekwute et al. 2011). At the end of the feeding trial, one bird from each of the replicates of a treatment was individually housed in a metabolic cage. They were fed their respective experimental diet. They were allowed to acclimatize for four days. Each daily fecal output during the acclimatization period was discarded. At the end of the acclimatization period, known quantity of their feed was fed daily and daily intake noted. Daily collection of feces was by placing a tray under the cage. Each daily fecal sample was weighed after which they were dried in an oven at $60^{\circ \mathrm{C}}$ till constant weight was reached. Proximate analysis was carried out according to AOAC (1990).
Table 1. Ingredient and composition of starter diets

\begin{tabular}{|c|c|c|c|c|c|}
\hline Ingredients (\%) & control & AGP & $\begin{array}{c}0.25 \% \\
F A\end{array}$ & $\begin{array}{c}0.50 \% \\
\text { FA }\end{array}$ & $\begin{array}{c}0.75 \% \\
\text { FA }\end{array}$ \\
\hline Maize & 53.00 & 53.00 & 53.00 & 53.00 & 53.00 \\
\hline Soybean meal & 30.00 & 30.00 & 30.00 & 30.00 & 30.00 \\
\hline Fish meal & 3.00 & 3.00 & 3.00 & 3.00 & 3.00 \\
\hline Palm kernel cake & 6.20 & 6.20 & 6.20 & 6.20 & 6.20 \\
\hline Wheat offal & 4.00 & 3.98 & 3.75 & 3.50 & 3.25 \\
\hline Bone meal & 3.00 & 3.00 & 3.00 & 3.00 & 3.00 \\
\hline Streptomycin & - & 0.02 & - & - & - \\
\hline FA & - & - & 0.25 & 0.50 & 0.75 \\
\hline Salt & 0.25 & 0.25 & 0.25 & 0.25 & 0.25 \\
\hline Lysine & 0.20 & 0.20 & 0.20 & 0.20 & 0.20 \\
\hline Methionine & 0.10 & 0.10 & 0.10 & 0.10 & 0.10 \\
\hline Premix* & 0.25 & 0.25 & 0.25 & 0.25 & 0.25 \\
\hline Total & 100 & 100 & 100 & 100 & 100 \\
\hline \multicolumn{6}{|c|}{ Nutrient Composition (\%) } \\
\hline Crude Protein & 22.35 & 22.35 & 22.30 & 22.28 & 22.22 \\
\hline Crude Fibre & 4.13 & 4.13 & 4.10 & 4.09 & 4.06 \\
\hline Ether Extract & 4.10 & 4.10 & 4.10 & 4.10 & 4.10 \\
\hline Total Ash & 8.00 & 8.00 & 8.00 & 8.00 & 8.00 \\
\hline Calcium** & 1.08 & 1.08 & 1.08 & 1.08 & 1.08 \\
\hline Phosphorus* & 1.01 & 1.01 & 1.01 & 1.01 & 1.01 \\
\hline Lysine** & 1.10 & 1.10 & 1.10 & 1.10 & 1.10 \\
\hline Methionine** & 0.50 & 0.50 & 0.50 & 0.50 & 0.50 \\
\hline $\begin{array}{l}\text { Energy (KcalME/ } \\
\text { kg diet)** }\end{array}$ & 2875 & 2875 & 2871 & 2867 & 2862 \\
\hline
\end{tabular}

AGP, antibiotic growth promoter (streptomycin); FA, formic acid; *, premix supplied per kg diet: vitamin A 15,000 IU, vitamin $D_{3} 13000$ IU, thiamin $2 \mathrm{mg}$, riboflavin $6 \mathrm{mg}$, pyridoxine $4 \mathrm{mg}$, niancin $40 \mathrm{mg}$, cobalamine $0.05 \mathrm{~g}$, biotin $0.08 \mathrm{mg}$, chooline chloride $0.05 \mathrm{~g}$, manganese $0.096 \mathrm{~g}$, zinc $0.06 \mathrm{~g}$, iron $0.024 \mathrm{~g}$, copper $0.006 \mathrm{~g}$, iodine $0.014 \mathrm{~g}$, selenium $0.24 \mathrm{mg}$, cobalt $0.024 \mathrm{mg}$ and antioxidant $0.125 \mathrm{~g}$; **, calculated

The Proximate result was used to calculate the moisture content of the fecal samples and nutrient digestibility as thus:

Moisture content of feces $=\underline{\text { Wet weight }- \text { Dry weight }} \times 100$ Wet weight

Digestibility $=$ Nutrient in feed - Nutrient in feces $\times 100$ Nutrient in feed

Data collected were subjected to analysis of variance according to Steel and Torrie (1980). 
Table 2. Ingredient and composition of finisher Diets

\begin{tabular}{|c|c|c|c|c|c|}
\hline Ingredients (\%) & control & AGP & $\begin{array}{l}0.25 \% \\
\text { FA }\end{array}$ & $\begin{array}{l}0.50 \% \\
\text { FA }\end{array}$ & $\begin{array}{l}0.75 \% \\
\text { FA }\end{array}$ \\
\hline Maize & 54.00 & 54.40 & 54.00 & 54.00 & 54.00 \\
\hline Soybean meal & 27.00 & 27.00 & 27.00 & 27.00 & 27.00 \\
\hline Palm kernel cake & 9.30 & 9.30 & 9.30 & 9.30 & 9.30 \\
\hline Wheat offal & 6.00 & 5.98 & 5.75 & 5.50 & 5.25 \\
\hline Bone meal & 3.00 & 3.00 & 3.00 & 3.00 & 3.00 \\
\hline Streptomycin & - & 0.02 & - & - & - \\
\hline FA & - & - & 0.25 & 0.50 & 0.75 \\
\hline Salt & 0.25 & 0.25 & 0.25 & 0.25 & 0.25 \\
\hline Lysine & 0.10 & 0.10 & 0.10 & 0.10 & 0.10 \\
\hline Methionine & 0.10 & 0.10 & 0.10 & 0.10 & 0.10 \\
\hline Premix* & 0.25 & 0.25 & 0.25 & 0.25 & 0.25 \\
\hline Total & 100 & 100 & 100 & 100 & 100 \\
\hline \multicolumn{6}{|c|}{ Nutrient Composition (\%) } \\
\hline Crude Protein & 20.45 & 20.45 & 20.41 & $20, .36$ & 20.32 \\
\hline Crude Fibre & 4.53 & 4.53 & 4.49 & 4.44 & 4.00 \\
\hline Ether Extract & 4.10 & 4.10 & 4.10 & 4.10 & 4.10 \\
\hline Total Ash & 8.00 & 8.00 & 8.00 & 8.00 & 8.00 \\
\hline Calcium** & 1.08 & 1.08 & 1.08 & 1.08 & 1.08 \\
\hline Phosphorus $^{\star \star}$ & 1.01 & 1.01 & 1.01 & 1.01 & 1.01 \\
\hline Lysine** & 1.10 & 1.10 & 1.10 & 1.10 & 1.10 \\
\hline Methionine ${ }^{\star \star}$ & 0.50 & 0.50 & 0.50 & 0.50 & 0.50 \\
\hline $\begin{array}{l}\text { Energy (KcalME/ } \\
\text { kg diet) }{ }^{\star \star}\end{array}$ & 2901 & 2901 & 2897 & 2893 & 2888 \\
\hline
\end{tabular}

AGP, antibiotic growth promoter (streptomycin); FA, formic acid; *, premix supplied per $\mathrm{kg}$ diet: vitamin A $15,000 \mathrm{IU}$, vitamin $D_{3} 13000$ $\mathrm{IU}$, thiamin $2 \mathrm{mg}$, riboflavin $6 \mathrm{mg}$, pyridoxine $4 \mathrm{mg}$, niancin $40 \mathrm{mg}$, cobalamine $0.05 \mathrm{~g}$, biotin $0.08 \mathrm{mg}$, chooline chloride $0.05 \mathrm{~g}$, manganese $0.096 \mathrm{~g}$, zinc $0.06 \mathrm{~g}$, iron $0.024 \mathrm{~g}$, copper $0.006 \mathrm{~g}$, iodine $0.014 \mathrm{~g}$, selenium $0.24 \mathrm{mg}$, cobalt $0.024 \mathrm{mg}$ and antioxidant $0.125 \mathrm{~g}$; **, calculated

\section{Results}

Effect of dietary streptomycin and FA on performance of starter broiler chicks is shown on Table 3. It was observed that there were no significant differences $(p>0.05)$ in final live weight and daily weight gain, though marginal differences occur. It could be noted also that as the level of formic acid was increased the final live weight was marginally reduced. Addition of $0.02 \%$ streptomycin, $0.50 \%$ and $0.75 \%$ FA significantly $(p<0.05)$ reduced both total and daily feed intake which assumed similar trend. There was no significant difference $(p>0.05)$ between the feed intake of $0.25 \%$ FA and the control. Chicks fed diets supplemented with streptomycin, $0.50 \%$ and $0.75 \%$ FA showed a significant $(p<0.05)$ improvement in feed: gain ratio as against the chicks fed control diet and $0.25 \%$ FA. Addition of $0.02 \%$ streptomycin, $0.50 \%$ and $0.75 \%$ FA culminated to reduction in protein intake.

Table 3. Effects of diets on growth performance of starter broiler chicks

\begin{tabular}{lccccc}
\hline Ingredients (\%) & Control & AGP & $0.25 \%$ & $0.50 \%$ & $0.75 \%$ \\
& & & FA & FA & FA \\
\hline Initial body weight (g) & 36.67 & 36.67 & 36.67 & 36.61 & 36.81 \\
Final body weight (g) & 524.67 & 531.67 & 531.67 & 507.67 & 470.33 \\
Daily gain (g) & 17.43 & 17.68 & 17.68 & 16.11 & 15.48 \\
Daily feed intake (g) & $39.30^{\mathrm{a}}$ & $30.83^{\mathrm{b}}$ & $39.39^{\mathrm{a}}$ & $31.37^{\mathrm{b}}$ & $31.11^{\mathrm{b}}$ \\
Feed: gain ratio & $2.25^{\mathrm{a}}$ & $1.74^{\mathrm{c}}$ & $2.23^{\mathrm{a}}$ & $1.95^{\mathrm{b}}$ & $2.01 \mathrm{~b}$ \\
Daily protein intake (g) & $8.80^{\mathrm{a}}$ & $6.91^{\mathrm{b}}$ & $8.78^{\mathrm{a}}$ & $6.93^{\mathrm{b}}$ & $6.91^{\mathrm{b}}$ \\
Protein efficiency ratio & $1.98^{\mathrm{c}}$ & $2.55^{\mathrm{a}}$ & $2.01^{\mathrm{c}}$ & $2.32^{\mathrm{b}}$ & $2.24^{\mathrm{b}}$ \\
\hline
\end{tabular}

$A G P$, antibiotic growth promoter (streptomycin), FA, formic acid; means with different superscripts in the same row differed significantly $(p<0.05)$

The effect of streptomycin and FA on growth performance of finisher broiler chickens has shown in Table 4. Final live weight was significantly influenced by treatment $(p<0.05)$. Inclusion of $0.02 \%$ streptomycin and $0.5 \%$ FA improved final live weight over the control and the other levels of FA. Better daily gain was also expressed by streptomycin and $0.5 \%$ FA compared to control. Total feed intake, daily feed intake and protein intake took similar trend in which streptomycin significantly $(p<0.05)$ increased feed and protein intakes.

Table 4. Effect of diets on growth performance of broiler finisher

\begin{tabular}{llllll}
\hline $\begin{array}{l}\text { Ingredients } \\
\text { (\%) }\end{array}$ & control & AGP & $0.25 \%$ & $0.50 \%$ & $0.75 \%$ \\
& & & FA & FA & FA \\
\hline Initial body weight (g) & 524.67 & 531.67 & 531.67 & 507.67 & 470.33 \\
Final body weight (g) & $1800.00^{c}$ & $2040.00^{\mathrm{a}}$ & $1810.00^{c}$ & $1900.00^{\mathrm{b}}$ & $1770.0^{\mathrm{d}}$ \\
Daily weight gain (g) & $45.55^{\mathrm{c}}$ & $53.87^{\mathrm{a}}$ & $45.66^{\mathrm{c}}$ & $50.44^{\mathrm{ab}}$ & $46.42^{\mathrm{bc}}$ \\
Daily feed intake & $128.96^{\mathrm{b}}$ & $144.64^{\mathrm{a}}$ & $129.06^{\mathrm{b}}$ & $127.93^{\mathrm{b}}$ & $126.24^{\mathrm{b}}$ \\
Feed : gain ratio & $2.83^{\mathrm{a}}$ & $2.68^{\mathrm{c}}$ & $2.83^{\mathrm{a}}$ & $2.54^{\mathrm{d}}$ & $2.73^{\mathrm{a}}$ \\
Daily protein intake (g) & $26.65^{\mathrm{b}}$ & $29.65^{\mathrm{a}}$ & $26.673^{\mathrm{b}}$ & $26.45^{\mathrm{b}}$ & $25.96^{\mathrm{b}}$ \\
Protein efficiency ratio & $1.71^{\mathrm{c}}$ & $1.82^{\mathrm{b}}$ & $1.71^{\mathrm{c}}$ & $1.91^{\mathrm{a}}$ & $1.79^{\mathrm{c}}$ \\
\hline
\end{tabular}

AGP, antibiotic growth promoter (streptomycin); FA, formic acid; Means with different superscript in the same row differed significantly $(p<0.05)$ 


\section{Effect of formic acid and Streptomycin on Broilers}

Better feed: gain ratio was significantly $(p<0.05)$ recorded by $0.5 \%$ formic FA followed by streptomycin. There was no significant difference ( $p>0.05$ ) between the feed: gain ratio of the control, $0.25 \%$ and $0.75 \%$ FA. Protein efficiency ratio was highest in $0.5 \%$ FA followed by streptomycin. The protein efficiency ratio of $0.25 \%, 0.75 \%$ and control did not differ significantly $(p>0.05)$

Addition of either streptomycin or FA to the diets did not significantly $(p>0.05)$ influence dry matter, crude fibre and ash digestibility (Table 5). However, both the antibiotic and organic acid at all levels $(p<0.05)$ gave better protein and ether extract digestibility compared to the control.

Table 5. Effect of Streptomycin and FA on Apparent Nutrient Finisher Broilers

\begin{tabular}{llllll}
\hline Ingredients (\%) & control & AGP & $0.25 \%$ & $0.50 \%$ & $0.75 \%$ \\
& & & FA & FA & FA \\
\hline Dry matter & 68.44 & 70.01 & 69.00 & 69.67 & 70.78 \\
Protein & $65.00^{\mathrm{b}}$ & $75.34^{\mathrm{a}}$ & $74.07^{\mathrm{a}}$ & $76.00^{\mathrm{a}}$ & $77.07^{\mathrm{a}}$ \\
Ether extract & $66.52^{\mathrm{b}}$ & $78.11^{\mathrm{a}}$ & $75.70^{\mathrm{a}}$ & $76.09^{\mathrm{a}}$ & $80.43^{\mathrm{a}}$ \\
Crude fibre & 35.77 & 36.99 & 35.04 & 36.88 & 37.03 \\
Ash & 58.88 & 58.90 & 59.03 & 60.10 & 60.55 \\
\hline
\end{tabular}

$A G P$, antibiotic growth promoter (streptomycin); FA, formic acid; Means with different superscript in the same row differed significantly $(p<0.05)$

\section{Discussion}

The nutrient composition of the experimental starter diets (Tables 1) conformed to the requirements of broilers raised in tropical environment (NRC 1994; Oluyemi and Roberts 2000). Marginal reduction of live weight as the level of FA was increased at starter phase is an indication that at certain higher level FA could induce poor growth. This result was in harmony with Owens et al. (2008) who reported no significant difference in the live weight of broiler chickens fed antibiotics and organic acid supplemented diets. However, this was in variance with the result of Ndelekwute et al. (2010) who observed higher live weight of starter chicks fed $0.25 \%$ FA compared to the control. The reduction in the feed intake at higher level of FA could be due to the strong taste associated with organic acids which would have induced repulsive effect to reduce the palatability of the feed, thereby reducing feed intake. On the part of streptomycin report showed that antibiotics tended to reduce the size of the intestine (Maynard et al. 1981). This could have led to low capacity of the intestine to hold enough feed resulting to low feed intake especially at young age. Similar result was reported by Leeson et al. (2005) who observed reduction in the feed consumption in groups fed $0.02 \%$ antibiotics and those fed $0.50 \%$ FA compared to the group fed control diet. Taylor (2001) also reported that one of the characteristics of antibiotics in feed was reduction in feed consumption. Reduction in feed intake would have contributed to the marginally lower live weight of chicks fed 0.5 and $0.75 \%$ FA. Obioha (1992) reported that body weight was related to feed intake. The improvement in feed: gain ratio resulting from feeding of $F A$ and streptomycin could possibly be due to some explanations offered elsewhere. Leeson et al. (2005) associated this to better utilization of nutrients resulting from modulating effect of antibiotics and organic acids due to their antibacterial effect and inducement of secretion of mucus. Organic acids are important in young monogastric animals for protein digestion which could improve feed utilization (Chowdhury et al. 2008). This result is in consonant with the reports of Vogt et al. (1981) who reported that organic acids improved the feed: gain ratio in broiler chickens. Leeson et al. (2005) had also reported better feed: gain ratio of birds fed dietary organic acids. Low protein intake was as a result of low feed intake as all diets were iso-proteineous. Though this reduction existed, they showed significantly $(p<0.05)$ better utilization of protein.

The nutrient composition of the experimental finisher diets (Tables 2) conformed to the requirements of broilers raised in tropical environment (NRC 1994; Oluyemi and Roberts 2000). The result at the finisher phase could be indicative of better utilization of nutrients resulting from inclusion of streptomycin or FA to the diets, which culminated to better performance. This agreed with Taylor (2001) and Abdel Fattah et al. (2008) that antibiotics and organic acids were respectively added to broiler diets for improved productivity. Birds that consumed diet containing $0.75 \%$ FA which recorded the lowest final live weight was an 
indication that at higher level FA could induce negative impact on growth of broilers. This indication was expressed at the starter phase when $0.75 \%$ FA reduced live weight marginally.

The non significant difference of the live weight at starter phase which later became significant at the finisher phase signified cross-over effect. This shows that for growth promoting effect of FA to be realized, broilers need to be exposed to it for a long period. Significant gain in weight recorded by streptomycin and FA was possible because according to Thomke and Elwinger (2004) antibiotics increased growth performance due to their role in combating pathogenic bacteria which retard growth, and that could have been responsible in this case. Also diets containing organic acids have been reported to give better weight gain than organic acid-free-diets, because of their ability to control pathogens and induce endogenous secretions (Dibner 2004). Improved feed intake at the finisher phase by streptomycin judging from the result of the starter phase, could be due to adaptive effect. Second, the feed intake of streptomycin group could have been influenced by the live weight. It could also mean that streptomycin modulated the gastro intestinal tract making it healthier and conditioning it to process feed better, resulting to increase in feed intake and body weight. Maynard et al. (1981) noted that antibiotic growth promoters could increase feed intake. Non significant effect in feed intake of control and all the levels of FA shows improvement on the side of FA as compared to the starter phase. This suggests also adaptive posture by birds that consumed FA diets. The results of feed: gain ratio and protein efficiency ratio had similar trend to the result of final live weight. Thomke and Elwinger (2004) and Abdel Fattah et al. (2008) respectively reported that streptomycin and organic acids could improve both live weight and feed: gain ratio. Ndelekwute et al. (2014b) have also reported the economic importance of formic acid in broiler diet. In a different report, Ndelekwute et al. (2014a) noted that $0.25 \%$ of acetic acid could not improve growth performance and suggested increasing the dietary level above $0.25 \%$ which this result has achieved.

Better protein and ether extract digestibility means that more energy and amino acids were available to the birds that consumed streptomycin or FA. The performance of birds fed streptomycin and FA at $0.50 \%$ level could be linked to this result. This result is in consonant with the report of Ndelekwute et al. (2011) who observed better nutrient digestibility using $0.25 \%$ of acetic, butyric, formic or citric acid, and Maynard et al. (1981) who stressed the importance of antibiotic in nutrient utilization by monogastric animals.

\section{Conclusion}

Though, inclusion of FA did not bring about better performance compared to streptomycin, 0.5\% FA performed better than the control and as such FA could be used to replace streptomycin and other antibiotics used as feed additives which have been banned or regulated in farm animal feeds. This is necessary because for now no negative effect of organic acids on man or farm animals has been reported (organic acids are part of metabolic processes of the body). It is therefore recommended that $0.5 \%$ level of FA could be used in the to replace of antibiotics in diets for broiler chickens.

\section{Reference}

Aalback BC and Taylor UM (2000). Prevalence of antibiotic-resistant Escherichia coli in Danish pigs and cattle. Science, 84: 14181422.

Abdel Fattah SA, El-San Houry MH, El-Medney NM, Abdel-Azeem F (2008). Thyroid activity organs morphology and performance of broiler chicks for supplemental organic acids. International Journal of Poultry Science, 7: 215-222.

AOAC (1990). Official Methods of Analysis. $14^{\text {th }}$ edition. Washington DC, USA.

Chowdhury RK, Islam KM, Martin PW and George GM (2008). Effect of formic and citric acids, avilamycin and their combination on the performance, tibia ash and immune status of broilers. Poultry Science, 88: 16161622.

Dibner J (2004). Organic acids: Can they replace antibiotic growth promoters. Feed International, 5: 14-16.

Leeson S, Namkung $\mathrm{H}$, Ankongiovarmi $\mathrm{H}$, Lee $\mathrm{EH}$ (2005). Effect of butyric and formic acids 


\section{Effect of formic acid and Streptomycin on Broilers}

on the performance and carcass yield of broiler chickens. Poultry Science, 84: 14181422.

Maynard LA, Loosli JK, Hintz HF and Warner RC (1981) Animal Nutrition $7^{\text {th }}$ Edition. Tata MC Graw Hill Pub. New Delhi, India. P. 122134.

Ndelekwute EK, Amaefule KU, Onen GE, Anigbogu NM, Opara JU (2010). Effect of diets treated with organic acids on the performance of starter broiler chicks. Proceedings of the $15^{\text {th }}$ Annual Conference of Animal Science Association, Nigeria. P. 456-458.

Ndelekwute EK, Amaefule KU, Anigbogu NM, Onen GE (2011). Effect of organic acidtreated diets on nutrient digestibility and fecal moisture of broiler chickens. Proceedings of the $36^{\text {th }}$ Annual Conference of Nigeria Society of Animal Production. P. $731-733$

Ndelekwute EK, Uzegbu HO, Madu HC and Assam EM (2012). Organic acids as feed additives in pig and poultry diets: A review. Nigeria Agricultural Journal, 43: 27-38.

Ndelekwute EK, Amaefule KU, Uzegbu $\mathrm{HO}$ and Okereke CO (2013). Effect of finisher diets treated with organic acids on carcass and internal organs of broiler chickens. Nigeria Journal of Animal Production, 40; 224 231.

Ndelekwute EK, Okonkwo AC, Umoh BI, Nwokoro C (2014a) Growth performance and economic returns of broiler chickens fed with acetic acid treated diets at finisher phase. Nigeria J ournal of Agriculture, Food and Environment, 10: 8-12.

Ndelekwute EK, Obi JI, Ekanem NJ and Mbaba EN (2014b). Effect of dietary stropmycin and formic acid on carcass, internal organs and economics of broiler chickens. Nigeria Journal of Agriculture, Food and Environment, 10: 34-38.

NRC (1994). Nutrition Requirements for Poultry. National Research Council, National Academy Press, Washington, DC, P. 33-34.

Obioha FC (1992). A Guide to Poultry production in the Tropics. $1^{\text {st }}$ Edition. Ecena Publication, Nigeria. P. 88-95.

Oluyemi JA and Roberts FA (2000). Poultry Production in Warm Wet Climate. $2^{\text {nd }}$
Edition. Spectrum Books Limited. Ibadan, Nigeria. P. 210.

Onifade AA, GM Babatunde (1997). Comparative response of broiler chicks to a high fiber diet supplemented with four antibiotics. Animal Feed Science and Technology, 64: 337-342.

Paul SK, Samanta G, Halder G and Biswas P (2007). Effect of a combination organic acid salts as antibiotic replacers on the performance and gut health of broiler chickens. Livestock Research and Rural Development, 19; 115-120.

Rodwell VW (2006). Catabolism of the carbon skeleton ofs of amino acids. In: Harper's Illustrated Chemistry. $27^{\text {th }}$ Edition (Murray RK, Granner DK, Rodwll VW), McGraw Hill, New York, USA. P. 254-269.

Steel GD and Torrie JH (1980). Principles and Procedures of Statistics. $2^{\text {nd }}$ Edition. Mc Graw Hill Book Co. Inc. New York. P. 204220.

Thomke BN, Elwinger BO (2004) Antimicrobial susceptibility patterns of thermophilic campylobacter spp. from humans, pigs, cattle and broilers in Denmark. Anti Ageing and Chemistry, 41; 2244-2250.

Taylor DE, Engberg J, Aarestrup FM, GernerSmidt P, Nachankin I (2001). Quinolone and Macrolide resistance in campylobacter jejuni and campylobactercoli: resistance mechanisms and trends in human isolates. Emerging Infectious Diseases, 7: 24-27.

Waldroup A, Kanlawato S, Mauromuos-Takos A (2005). Performance characteristics and microbiological aspects of broiler fed diets supplemented with organic acids. Journal of Food Production, 58: 482 - 489.

Windisch W, Schedle K, Pllitzner C, Kroismayr A (2007). Use of Phytogenic products as feed additives for swine and poultry. Journal of Animal Science, 86: 40-148.

Wolfenden $A D$, Vicente JL, Higgins JP, Andreattifiljo RL, Higgins SE, Hargis BM, Tellez G (2007). Effect of organic acids and proboitics on salmonella enteritidis infection in broiler chickens. International J ournal of Poultry Science, 6: 403-405. 